\title{
A escrita da história
}

The writing of history

Marly Motta

Estudos sobre a escrita da história Manoel Luiz Salgado Guimarães (org.) Rio de Faneiro: 7 Letras, 2006

Concebidos originalmente para serem apresentados no Encontro de Historiografia e História Política, promovido pelo Programa de Pós-Graduação em História Social do IFCS/UFRJ em outubro de 2005, os 12 artigos reunidos no livro Estudos sobre a escrita da história constituem um amplo e variado manancial para os historiadores que tomam a historiografia como objeto de estudo. $\mathrm{O}$ alerta de que estamos caminhando por uma área nova da pesquisa histórica é dado logo no início da apresentação feita por Carlos Fico, citando o coordenador do livro, Manoel Salgado Guimarães. Prisioneiros de tradições que vinham de suas ori-

Marly Motta é doutora em história e professora associada do CPDOC/FGV (marly.motta@fgv.br) Este texto foi recebido em 28 de abril e aprovado para publicação em 12 de maio de 2008

Estudos Históricos, Rio de Janeiro, vol. 21, nº 41, janeiro-junho de 2008, p. 115-118. 
gens, os estudos historiográficos ficaram, durante muito tempo, a cargo dos filósofos da história, mesmo porque os historiadores de ofício viam com temor a possibilidade de tomar a si próprios e à sua produção como objeto de reflexão e de análise.

Tratada, portanto, como objeto de estudo da história, a historiografia foi submetida aos procedimentos clássicos de uma pesquisa histórica, na qual, sabemos bem, é indispensável o estabelecimento de determinados marcos temporais. Por isso mesmo, o trabalho que abre o livro, "Tempos do mundo, história, escrita da história", apresenta o conceito de "registros de historicidade", proposto por François Hartog para se entender os "diferentes modos de articulação das categorias do passado, do presente e do futuro". O chamado "antigo regime de historicidade" corresponde ao paradigma da história como "mestra da vida" - o passado está presente, e é nele que se deve buscar os modelos a copiar. Marco da experiência européia a partir do final do século XVIII, a idéia de progresso, somada à concepção de história como processo, transformou o tempo em ator histórico, jogou para o futuro a responsabilidade de lançar luz sobre o presente e o passado, e assinalou a passagem para o que Hartog chama de "moderno regime de historicidade".

A premissa básica que orienta o livro é de que a trajetória da escrita da história e da institucionalização da disciplina é histórica. Em seu trabalho sobre a historiografia argentina na virada do século XIX para o XX, Fernando Devoto analisa de que maneira o "clima" positivista - mais que a doutrina - foi o elemento que, naquele momento, moldou a construção dos relatos históricos. Para o leitor, fica a tentação de buscar comparações, e de entender o projeto que orientou a escrita da história no Brasil oitocentista. Nesse sentido, o trabalho de Manoel Salgado rompe com a tradicional dicotomia que opõe a história iluminista universalista (século XVIII) à disciplina histórica fundada pelo historicismo (século XIX). Com base em fontes primárias, o estudo revela as disputas e, sobretudo, as relações que se operaram no Instituto Histórico e Geográfico Brasileiro entre a tradição das Luzes, que buscava a definição de um "sentido geral" para a história da jovem nação, e o compromisso romântico da escrita de uma história nacional, preocupada, acima de tudo, com a observação e identificação de suas "marcas particulares". A conexão entre esses dois projetos intelectuais fica evidente na trajetória de Feliciano Fernandes Pinheiro, membro da Casa Literária do Arco do Cego (1799-1801) e primeiro presidente do IHGB (1838-47), exemplo de saber a serviço da Ilustração e do Estado.

Uma preocupação invadia corações e mentes desses intelectuais voltados para a tarefa de escrever a história do Brasil: quem somos? de onde viemos? Os artigos de Temístocles Cezar e Rodrigo Turín tomam esse tema como objeto, e mostram as profundas divergências dentro do IHGB em torno da questão indí- 
gena. Duro crítico do romantismo indianista, Francisco Adolfo de Varnhagen, ao mesmo tempo em que descartou os tupis como "donos" da terra e os colocou na condição de seus "últimos invasores", desacreditava da possibilidade de serem eles convertidos à civilização. Que tipo de discurso, portanto, daria conta da "obscura história" in dígena? O etnográfico ou o histórico? A resposta se encontrava nas diferentes percepções que existiam sobre o "índio brasileiro". Seria ele, dentro da tradição iluminista, representante da infância da humanidade, necessitando, por isso mesmo, ser catequizado para vir a ter consciência de sua historicidade? Ou representaria a antiga civilização tupi, agora em plena decadência, bastando recuperar os valores do passado para que ele rapidamente reconhecesse as práticas e os valores da civilização? Em comum, havia a crença de que ao homem civilizado caberia catequizar os primitivos ou os decaídos; em jogo, o "duplo movimento de englobamento e hierarquização da alteridade”, peça importante para a construção do Império do Brasil.

"Historiador: cientista ou literato?" Essa questão, que abre o estudo de Taíse Quadros da Silva sobre a "erudição ilustrada" de Varnhagen, serve de pano de fundo a três outros artigos. Um deles, de autoria de Maria da Glória de Oliveira, é sobre a "ida aos arquivos" empreendida por Capistrano de Abreu no afã de acumular documentos, sem o que considerava ser "prematuro" escrever a história do Brasil. Construídos como eixos organizadores da tradição histórica no Brasil, Varnhagen e Capistrano enfrentaram, cada um a seu modo, o desafio da pesquisa e da escrita da história. O primeiro viu-se diante da indefinição em relação ao estatuto das práticas do historiador, freqüentemente confundido com o "erudito" ou o "literato". A Capistrano, em primeiro lugar, cabia ser original, ou seja, distinguir-se de Varnhagen; ao mesmo tempo, precisava testar as possibilidades, na produção do texto de história, de articular as operações de pesquisa e investigação às da narrativa. É dentro da mesma problemática das relações entre o historiador e o literato que se inserem os trabalhos de Francisco José Alves e de Fernando Nicolazzi sobre Euclides da Cunha e Gilberto Freyre, respectivamente. O foco de suas análises reside na capacidade do "olhar etnográfico" que ambos os escritores possuíram quando, na condição de "viajantes", se empenharam na descrição da guerra de Canudos ou do Nordeste colonial.

A difusão do conhecimento histórico e a institucionalização da disciplina histórica são os temas dos trabalhos de Lucia Guimarães e Marieta de Moraes Ferreira, respectivamente. Tomando como objeto dois congressos de história realizados no IHGB - o I Congresso, em 1914, e o IV Congresso, em 1949 -, o artigo de Lucia revela o conjunto de questões que marcou a historiografia brasileira em contextos bem diferentes. No de 1914, prevaleceram as diretrizes da escola oitocentista capitaneada por Varnhagen, sintonizadas com as principais tendên- 
cias européias representadas pela "escola metódica" de Langlois e Seignobos. Aqui, a escrita da história deveria possuir um forte conteúdo pragmático, voltado para a produção de figuras exemplares e lições de civismo. Já o Congresso de 1949, ao escolher a história da colônia como seu recorte específico, revela a forte influência de Capistrano de Abreu. Trabalhos voltados para a ocupação e o povoamento do interior, estudos econômicos seguindo o modelo dos mestres franceses que vieram para a Universidade de São Paulo (USP) e a Universidade do Distrito Federal (UDF), ao mesmo tempo que se afinavam com as novas tendências historiográficas, apresentavam conexões com a política brasileira expansionista que marcou a virada para os anos 1950 .

O artigo de Marieta, ao propor a comparação entre dois cursos de história criados nas décadas de 1930 e 1940 - o da UDF e o da Faculdade Nacional de Filosofia (FNFi) da Universidade do Brasil -, permite analisar a institucionalização da disciplina histórica como um campo aberto a disputas em torno de diferentes modelos político-ideológicos, e de diversas concepções de história e de formação do historiador. Enquanto o curso de história na UDF se pautou por uma história social da civilização, com foco na formação de profissionais voltados para o ensino e a pesquisa, o da FNFi, sintonizado com a tradição do IHGB, investiu na história política como base para a construção da nação e da identidade nacional, visando, sobretudo, a formar professores para lecionar no ensino secundário.

Certamente, o leitor preferencial de Estudos sobre a escrita da história será o profissional de história. Mas isso não significa que outros leitores não possam se interessar por uma obra que lança a história no universo conturbado de possibilidades, conflitos e disputas. 